\title{
\begin{tabular}{l|l|l} 
Jurnal Eksplorasi Akuntansi & e-ISSN : 2656-3649 (Online) \\
Vol. 3, No 1, Februari 2021, Hal 218-232 & http://jea.ppj.unp.ac.id/index.php/jea
\end{tabular}
}

\section{Pengaruh Faktor Keuangan dan Faktor Non Keuangan Terhadap Kinerja Pemerintah Daerah di Indonesia}

\author{
Nadila Sundari ${ }^{1}$, Fefri Indra Arza ${ }^{2}$ \\ ${ }^{1,2}$ Jurusan Akuntansi Fakultas Ekonomi Universitas Negeri Padang \\ *Korespodensi: nadilasundari1710@gmail.com
}

\begin{abstract}
This study aims to provide empirical evidence about the influence of financial factors (Size, Wealth, Intergovermental Revenue, Leverage and Capital Expenditures) and non-financial factors (Population, Legislative Size, Service Period and Age of Regional Heads) on the performance of local governments in Indonesia. evaluation of the performance of local government administration (EKPPD) as the main source. The population used in this study is the district / city government in 2018 consisting of 415 districts and 93 cities in Indonesia. The research sample was taken using purposive sampling method, the total sample obtained was 39 data. The results showed that the variables size, wealth, intergovernmental revenue, leverage, capital expenditure, legislative size, tenure of regional heads and age of regional heads had no effect on local government performance, while population had an effect on local government performance in Indonesia.
\end{abstract}

Keywords: financial factors; non-financial factors; performance of local governments

How to cite

Sundari, N. \& Arza, F.I. (2019). Pengaruh Faktor Keuangan dan Faktor Non Keuangan Terhadap Kinerja Pemerintah Daerah di Indonesia. Jurnal Eksplorasi Akuntansi, $3(1), 218-232$.

\section{PENDAHULUAN}

Dengan diberlakukannya UU No. 22 tahun 1999 yang mengatur tentang kebijakan pemerintah Indonesia mengenai kebijakan otonomi daerah yang telah diubah menjadi UU No. 32 tahun 2004 mengenai otonomi daerah, dan perubahan terakhir menjadi UU No. 23 tahun 2014 mengenai pemerintah daerah. Adanya otonomi daerah, pemerintah daerah memiliki wewenang untuk mengelola dan mengatur sumber daya sesuai dengan kemampuannya, serta mengurus sendiri urusan pemerintahnya.

Kinerja adalah gambaran mengenai tingkat pencapaian pelaksanaan suatu kegiatan atau program atau kebijaksanaan dalam mewujudkan sasaran, tujuan, misi, visi organisasi yang terutang dalam perumusan skema strategis (strategic planning) suatu organisasi, Bastian (2001:329). Pengukuran kinerja pemerintah daerah penting untuk dilakukan untuk melihat apakah suatu daerah sudah mampu menjalankan pemerintahannya dengan baik atau sebaliknya dan hasil pengukuran kinerja ini dapat dilihat apakah suatu daerah sudah mampu menggali potensi-potensi yang dimiliki daerah tersebut. Pengukuran kinerja pemerintah salah satunya dapat dilakukan melalui Evaluasi Kinerja Penyelenggaraan Pemerintah Daerah (EKPPD). 
Berdasarkan pasal 5 Permendagri No.73 tahun 2009 menjelaskan bahwa yang menjadi sumber informasi pertama dalam EKPPD adalah Laporan Penyelenggaraan Pemerintah Daerah (LPPD). Kriteria penilaian yang ditetapkan terhadap skor kinerja memperoleh penilaian dengan kategori ST (Sangat Tinggi) T (Tinggi) S (Sedang) dan R (Rendah). Penilaian skor diambil dari tingkat penilaian indikator-indikator yang telah dicapai oleh pemerintah daerah. Skor yang diberikan tergantung dengan tingkat kematangan dari pemerintah daerah tesebut. Jumlah skor yang diperoleh dari masing-masing pemerintah daerah akan menentukan status peringkat yang diraih masing-masing daerah. Penelitian sebelumnya telah meneliti kinerja pemerintah pada lingkup pemerintah kabupaten dan provinsi Jawa barat tahun 2014-2016 yang dilakukan oleh Aminah (2019), sehingga peneliti melakukan penelitian pada tingkat daerah kabupaten/kota se Indonesia agar memiliki keterbaruan dengan penelitian sebelumnya.

Berdasarkan latar belakang diatas, maka peneliti tertarik untuk melakukan penelitian dengan tujuan untuk mengetahui pengaruh faktor keuangan dan faktor non keuangan terhadap kinerja pemerintah daerah di Indonesia. Sehingga dapat dijadikan pedoman oleh pemerintah daerah dalam penyelenggaraan pemerintahannya.

\section{REVIU LITERATUR DAN HIPOTESIS}

\section{Agensi Teori/ TheoryAgency}

Teori utama yang mendasari penelitian mengenai pengaruh faktor keuangan dan faktor non keuangan terhadap kinerja pemerintah daerah dijelaskan melalui teori agensi. Bergman dan Lane (1990) menyatakan bahwa kerangka hubungan prinsipal agen merupakan suatu pendekatan yang sangat penting untuk menganalisis komitmen-komitmen kebijakan publik. Jensen dan Meckling (1976) telah menggambarkan adanya hubungan kerja antara pemilik (principal) dengan manajemen (agen).

\section{Theory Stewardship}

Theory Stewardship menggambarkan bahwa tidak ada suatu keadaan situasi para manajemen termotivasi untuk tujuan-tujuan individu melainkan lebih fokus untuk tujuan sasaran utama yaitu kepentingan organisasi, Donaldson dan Davis (1991) dalam Anton (2010). Teori stewardship merupakan teori yang menggambarkan situasi dimana para manajer tidak termotivasi oleh tujuan-tujuan individu tetapi lebih untuk mencapai sasaran hasil untuk kepentingan organisasi.

\section{Pengaruh Ukuran (Size) Pemerintah Terhadap Kinerja Pemerintah Daerah Di Indonesia}

Untuk tercapainya tujuan Pemerintah daerah diperlukan sumber daya dan fasilitas yang memadai untuk memberikan pelayanan publik kepada masyarakat. Semakin besar ukuran daerah semakin besarnya total aset pemerintah daerah, maka semakin tinggi pula kinerja pemerintah daerah, Kusumawardhani (2012). Dari uraian di atas maka hipotesis di uji adalah:

$\mathbf{H}_{1}$ : Ukuran (size) pemerintah berpengaruh signifikan positif terhadap kinerja pemerintah daerah di Indonesia.

\section{Pengaruh Wealth Terhadap Kinerja Pemerintah Di Indonesia}

Wealth atau kemakmuran adalah kemampuan suatu daerah dalam membiayai kebutuhan. kemakmuran suatu daerah dilihat dari besarnya tingkat pendapatan asli daerah. PAD diharapkan mampu memperoleh dana nyang besar sehingga pelayanan kepada masyarakat dapat dilaksanakan dengan baik. sehingga semakin besar PAD diharapkan kinerja pemerintah semakin baik. Dari uraian di atas maka hipotesis di uji adalah: 
$\mathbf{H}_{2}$ : Kemakmuran (wealth) berpangaruh signifikan positif terhadap kinerja pemerintah daerah di Indonesia.

\section{Pengaruh Intergovermental Revenue terhadap Kinerja Pemerintah di Indonesia}

Besarnya dana perimbangan menunjukan bahwa suatu daerah masih bergantung dengan pemerintah pusat sehingga dapat dikatakan suatu daerah belum mampu menggali potensi kekayann yang dimiliki oleh daerahnya. Dari uraian di atas maka hipotesis di uji adalah:

$\mathbf{H}_{3}$ : Intergovermental revenue berpengaruh terhadap kinerja pemerintah daerah kabupaten/kota di Indonesia.

\section{Pengaruh leverage terhadap Kinerja Pemerintah di Indonesia}

Leverage adalah Perbandingan antara utang dan modal. Sebagaimana semakin besar leverage maka semakin besar ketergantungan entitas pada pihak luar karena semakin besar utang yang dimiliki entitas tersebut maka semakin rendah kinerja keuangan entitas tersebut. Sumarjo (2010) dalam penelitianyamenyatakan bahwa dengan semakin besar leverage suatu daerah maka semakin menunjukkan bahwa entitas tersebut tidak mampu dalam membiayai operasionalnya sendiri karena masih membutuhkan dana dari pihak eksternal. Dari uraian di atas maka hipotesis di uji adalah:

H4: Leverage berpengaruh signifikan positif terhadap kinerja pemerintah daerah di Indonesia.

\section{Pengaruh Belanja Modal terhadap Kinerja Pemerintah di Indonesia.}

Suatu daerah memiliki belanja modal yang besar maka dapat dikatakan program-program yang akan dijalankan pemerintah daerah semakin banyak sehingga mampu meningkatkan pelayanan publik sehingga berdampak dapat meningkatkan kinerja pemerintah. Dari uraian di atas maka hipotesis di uji adalah:

H5: Belanja modal berpangaruh signifikan positif terhadap kinerja pemerintah daerah di Indonesia.

\section{Pengaruh Jumlah Penduduk Terhadap Kinerja Pemerintah Di Indonesia.}

Darmanto (2012) dalam penelitiannya menyatakan bahwa kepadatan penduduk terkait dengan kinerja keuangan pemerintah daerah. pada saat jumlah penduduk mengalami peningkatan maka menyebabkan peningkatan permintaan efisiensi pemerintah daerah untuk memberikan pelayanan yang baik terhadap publik. Dari uraian di atas maka hipotesis di uji adalah:

$\mathbf{H}_{6}$ : Jumlah penduduk berpengaruh signifikan positif terhadap kinerja pemerintah daerah di Indonesia.

\section{Pengaruh Ukuran Legislatif terhadap Kinerja Pemerintah di Indonesia.}

Besarnya jumlah anggota Dewan Perwakilan Rakyat (DPRD) diharapkan dapat meningkatkan pengawasan terhadap pemerintah daerah sehingga berdampak dengan adanya peningkatan kinerja pemerintah daerah Sumarjo (2010). Kusumawardani (2012) dalam penelitiannya menyatakan bahwa secara logika semakin tinggi tingkat pengawasan maka semakin tinggi pula tingkat tanggung jawab dan tingkat kemauan dalam bekerja. Dari uraian di atas maka hipotesis di uji adalah:

$\mathbf{H}_{7}$ : Ukuran legislatif berpangaruh signifikan positif terhadap kinerja pemerintah daerah di Indonesia.

Pengaruh masa Masa Jabatan kepala daerah terhadap kinerja pemerintah di Indonesia. Pengalaman kepala daerah dapat dikaitkan dengan lamanya masa jabatan. Semakin lama masa jabatannya maka semakin banyak pula pengalaman yang dimiliki. Pengalaman kerja 
yang cukup yang dimiliki oleh kepala daerah diharapkan bisa beradaptasi dengan perubahan yang terjadi dan diharapkan dapat membuat suatu hal yang baru untuk mencapai kinerja pemerintah yang baik, Sutaryo (2013). Dari uraian di atas maka hipotesis di uji adalah:

H9: Masa jabatan berpangaruh signifikan positif terhadap kinerja pemerintah daerah di Indonesia.

\section{Pengaruh Umur Kepala Daerah terhadap kinerja Pemerintah di Indonesia}

Umur seorang manajer dapat menggambarkan kedewasaan dan kematangan seseorang, sehingga dengan umur kepala daerah yang tinggi mengindikasikan kedewasaan dan kematangan dalam berpikir yang berakibat pada pengambilan keputusan yang lebih baik dalam pengelolaan keuangan daerah dan mampu mencapai kinerja keuangan yang lebih baik, Sutaryo (2013).

H9: Umur kepala daerah berpangaruh signifikan positif terhadap Kinerja pemerintah Daerah di Indonesia.

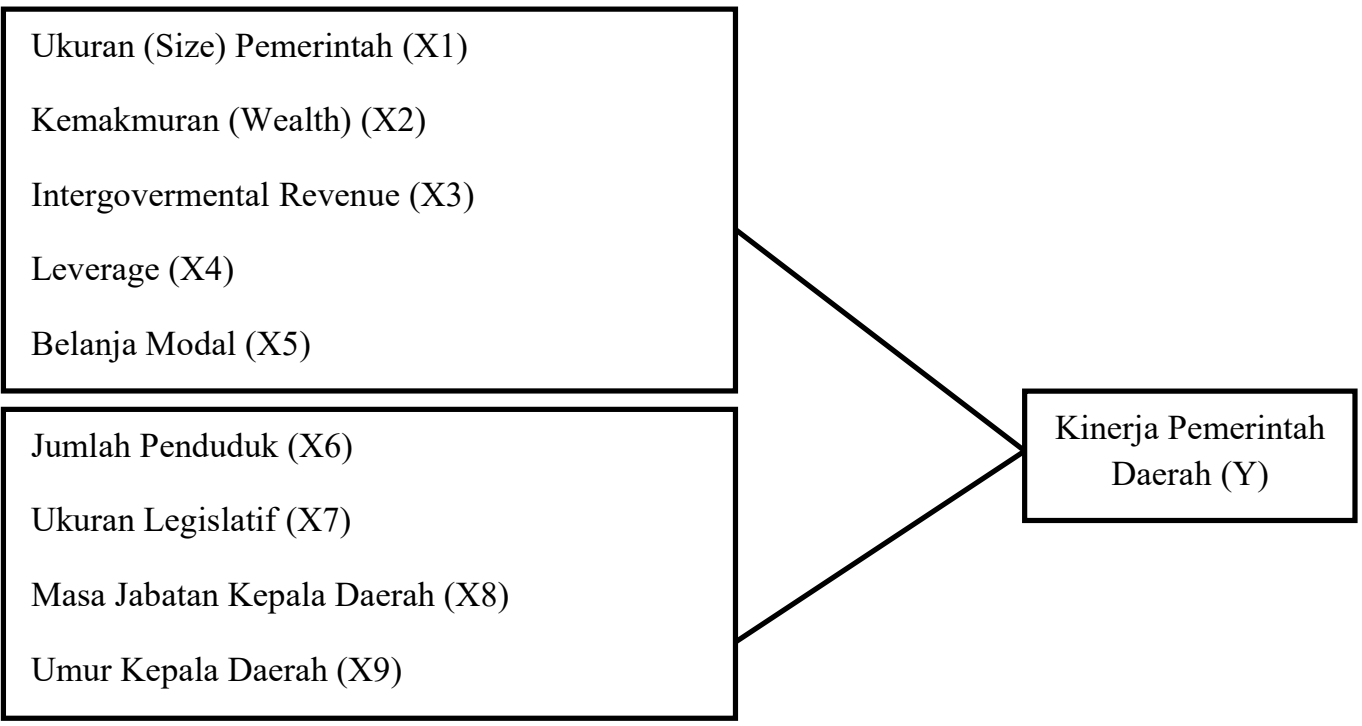

Gambar 1. Kerangka Konseptual

\section{METODE PENELITIAN}

\section{Jenis Penelitian}

Jenis penelitian yang digunakan adalah kausatif kerena melihat pengaruh antar variabel dari faktor keuangan dan faktor non keuangan terhadap kinerja pemerintah daerah.

\section{Populasi dan Sampel}

Populasi pada penelitian ini adalah Pemerintah daerah kabupaten/kota di Indonesia yang terdiri dari 415 Kabupaten dan 93 kota.

Pada penelitian ini peneliti mengambil metode pemilihan sampel adalah purposive sampling. Purposive sampling dilakukan dengan menentukan sampel dari populasi berdasarkan beberapa kriteria yang di pilih penulis. Kriteria yang digunakan adalah :

1. Pemerintah kabupaten/kota yang sudah mempublikasi laporan keuangan tahun 2018.

2. Pemerintah kabupaten/kota yang menyediakan informasi yang lengkap sesuai kebutuhan penelitian. 


\section{Data dan Sumber Data}

Jenis data pada Penelitian ini menggunakan data sekunder yaitu data yang di ambil dari hasil Evaluasi Kinerja Penyelenggaraan Pemerintah Daerah (EKPPD) dalam bentuk LPPD yang telah dipublikasikan oleh Kemendagri dalam keputusan Menteri Dalam Negeri Nomor 10053 Tahun 2018, Badan Pusat Statistik dan LKPD 2018 yang telah dipublikasikan .

\section{Teknik Pengumpulan Data}

Teknik pengumpulan data yang digunakan dalam penelitian ini adalah metode dokumentasi atau studi pustaka. Dokumentasi dilakukan dengan mengumpulkan data-data dari Faktor Keuangan dan Non Keuangan yang dapat berpengaruh terhadap kinerja Pemerintah.

\section{Pengujian Hipotesis}

Tujuan Analisis regresi linier berganda adalah untuk meramalkan bagaimana keadaan (naik turunnya) variabel dependen, apabila dua atau lebih variabel independen sebagai faktor prediator dimanipulasi (dinaik turunkan nilainya). Jadi, menurut Sugiyono (2014:277)analisis regresi berganda akan dilakukan bila jumlah variabel independennya minimal dua.

Maka persamaan regresi linier bergandanya adalah sebagai berikut:

$$
\mathbf{Y}=\mathbf{a}+\mathbf{b}_{1} \mathbf{X}_{1}+\mathbf{b}_{2} \mathbf{X}_{2}+\mathbf{b}_{3} \mathbf{X}_{3}+\mathbf{b}_{4} \mathbf{X}_{4}+\mathbf{b}_{5} \mathbf{X}_{5}+\mathbf{b}_{6} \mathbf{X}_{6}+\mathbf{b}_{7} \mathbf{X}_{7}+\mathbf{b}_{8} \mathbf{X}_{8}+\mathbf{b}_{9} \mathbf{X}_{9}+\mathbf{b}_{10} \mathbf{X}_{10}
$$

\section{Uji Simultan (Uji F) `}

Uji F bertujuan untuk mengetahui apakah variabel bebas (independen) secara bersama-sama berpengaruh terhadap variabel terikat (dependen), Ghozali $(2016 ; 96)$.

\section{Koefisien Determinasi $\left(\mathbf{R}^{2}\right)$}

Koefisien determinasi $\mathrm{R}^{2}$ adalah untuk mengukur tingkat kemampuan model dalam menerangkan variabel - variabel dependen Ghozali (2016;95).

\section{Uji Parsial (Uji t)}

Uji t digunakan untuk melihat pengaruh masing-masing variabel bebas (independen) secara parsial terhadap variabel terikat (dependen).

\section{Metode Analisis Data}

Metode analisis data yang digunakan dalam penelitian ini adalah analisis regresi linear berganda yang dianalisis menggunakan SPSS 25. Pengujian yang dilakukan adalah, Analisis statistik descriptive, uji asumsi klasik, pengujian hipotesis, dan uji kelayakan model.

\section{Defenisi Operasional \\ Variabel Independen}

Variabel Independen dalam penelitian ini adalah faktor keuangan dan faktor non keuangan.

\section{Faktor Keuangan}

Ukuran (size) pemerintah adalah yang diukur dengan menggunakan total Asset yang bersumber dari neraca yang dihitung dengan menggunakan log natura. Wealth atautingkat kekayaan yang dimiliki oleh suatu daerah diukur dengan membandingkan Total pendapatan dengan Intergovermental Revenue atau disebut dana perimbangan diukur degan membandingkan nilai total dana perimbangan dengan total pendapatan. Leverage merupakan perbandingan antara utang dan modal. pada penelitian ini leverage diukur dengan menggunakan total debt to equity dan belanja modal diukur melalui besarnya target alokasi belanja daerah setiap tahun anggaran. 


\section{Faktor Non Keuangan}

Peneliti mengambil beberapa variabel seperti, ukuran Legislatif diukur dengan jumlah anggota DPRD yang ada pada suatu daerah, jumlah penduduk diukurdengan jumlah penduduk yang bersumber dari BPS, masa jabatan dilihat dari periode jabatan kepala daerah dan umur kepala daerah di lihat dari usia kepala daerah yang menjabat.

\section{Variabel Dependen}

Variabel dependen adalah variabel yang muncul sebagai akibat dari adanya pengaruh dari variabel independen. Variabel dependen dalam penelitian ini adalah kinerja pemerintah daerah yang diukur dari skor hasil Evaluasi Kinerja Penyelenggaraan Pemerintah Daerah (EKPPD) yang dikeluarkan oleh Kemendagri tahun 2018.

\section{HASIL DAN PEMBAHASAN Sampel Penelitian}

Tabel 1

Purposive Sampling

\begin{tabular}{lc}
\hline \multicolumn{1}{c}{ Kriteria Sampel } & Jumlah \\
\hline Jumlah LKPPD Kabupaten/Kota di Indonesia & 513 \\
\hline $\begin{array}{l}\text { Jumlah LKPPD yang belum di publikasikan oleh pemerintah Kab/Kota di } \\
\text { Indonesia tahun 2018 }\end{array}$ & $(465)$ \\
\hline $\begin{array}{l}\text { Pemerintah Kab/kota yang tidak menyediakan informasi lengkap sesuai } \\
\text { kebutuhan penelitian }\end{array}$ & $(9)$ \\
\hline Jumlah Sampel & $\mathbf{3 9}$ \\
\hline
\end{tabular}

Subjek penelititan ini adalah peemerintah daerah kabupaten/kota di Indonesia yang berjumlah sebanyak 513 Kabupaten/kota. Data pada penelitian ini merupakan data sekunder yang diperoleh dari hasil Evaluasi kinerja pemerintah daerah, BPS dan LKPD Tahun 2018. Sehingga diperoleh sampel sebanyak 39 kabupaten/kota di Indonesia yang memenuhi kriteria penelitian

\section{Analisis Statistik Deskriptif}

Analisis ini digunakan untuk menyajikan dan menganalisis data menggunakan perhitungan untuk memperjelas karakteristik dan keadaan data yang bersangkutan (Ghozali, 2011).

\section{Uji Normalitas}

Pada pengujian normalitas menggunakan uji Kolmogorv-Smirnov. Jika nilai signifikansi > 0,05 maka Ho diterima (berdistribusi normal) sedangkan jika nilai signifikansi $<0,05$ maka Ho ditolak (tidak berdistribusi normal) (Ghozali, 2016). 


\section{Tabel 2}

Analisis Statistik Variabel Penelitian

\begin{tabular}{|c|c|c|c|c|c|}
\hline \multicolumn{6}{|c|}{ Descriptive Statistics } \\
\hline & $\mathrm{N}$ & Minimum & Maximum & Mean & Std. Deviation \\
\hline $\begin{array}{c}\text { Ukuran } \\
\text { Pemerintah } \\
\text { (Size) }\end{array}$ & 39 & 282202747,00 & 3138673348,00 & 2664661142,7436 & 700389523,70285 \\
\hline $\begin{array}{l}\text { kemakmuran } \\
\text { (Wealth) }\end{array}$ & 39 & 220888004,00 & 8734741756,00 & 3027537990,2308 & 1966590835,70108 \\
\hline $\begin{array}{l}\text { Intergovermen } \\
\text { tal Revenue }\end{array}$ & 39 & 26,00 & 94,00 & 71,0769 & 13,80577 \\
\hline Leverage & 39 & 9,12 & 83465568,00 & 12612168,1314 & 16912212,23736 \\
\hline Belanja Modal & 39 & 7752774879800,00 & $\begin{array}{c}24300610393094 \\
5,00 \\
\end{array}$ & $\begin{array}{c}36441328386716, \\
4000\end{array}$ & $\begin{array}{c}37739459824031,200 \\
00 \\
\end{array}$ \\
\hline $\begin{array}{c}\text { Jumlah } \\
\text { Penduduk }\end{array}$ & 39 & 69776,00 & 2900000,00 & 784723,8718 & 641884,27613 \\
\hline $\begin{array}{l}\text { Jumlah } \\
\text { Anggota } \\
\text { DPRD } \\
\end{array}$ & 39 & 20,00 & 50,00 & 37,8205 & 10,86974 \\
\hline $\begin{array}{c}\text { Masa Jabatan } \\
\text { Kepala Daerah } \\
\end{array}$ & 39 & 3,00 & 10,00 & 7,4872 & 2,58408 \\
\hline $\begin{array}{l}\text { Umur Kepala } \\
\text { Daerah }\end{array}$ & 39 & 31,00 & 71,00 & 54,3077 & 10,21906 \\
\hline $\begin{array}{c}\text { Kinerja } \\
\text { Pemerintah } \\
\text { Daerah } \\
\end{array}$ & 39 & 20103,00 & 35259,00 & 31349,0256 & 2927,82725 \\
\hline $\begin{array}{l}\text { Valid N } \\
\text { (listwise) }\end{array}$ & 39 & & & & \\
\hline
\end{tabular}

Tabel 3

Hasil Uji Normalitas

\begin{tabular}{llr}
\hline \multicolumn{3}{c}{ One-Sample Kolmogorov-Smirnov Test } \\
\hline $\mathrm{N}$ & \multicolumn{2}{c}{$\begin{array}{c}\text { Unstandardized } \\
\text { Residual }\end{array}$} \\
\hline Normal Parameters & & 39 \\
& Mean & 0,0000000 \\
\cline { 2 - 3 } & Std. Deviation & 2227,83426014 \\
\hline Most Extreme Differences & Absolute & 0,059 \\
\cline { 2 - 3 } & Positive & 0,049 \\
\cline { 2 - 3 } & Negative & $-0,059$ \\
\hline Test Statistic & & 0,059 \\
\hline Asymp. Sig. (2-tailed) & & $.200^{\mathrm{c}, \mathrm{d}}$ \\
\hline a. Test distribution is Normal. & \\
\hline b. Calculated from data. & \\
\hline c. Lilliefors Significance Correction. & \\
\hline d. This is a lower bound of the true significance. & \\
\hline
\end{tabular}

\section{Uji multikolinearitas}

Uji multikolinearitas adalah untuk menguji apakah model regresi ditemukan adanya korelasi antar variabel independen Ghozali (2016). Berdasarkan hasil pengujian multikolineritas, dapat diketahui bahwa semua variabel independen nilai $(V I F)<10,00$ dan nilai Tolerance $>$ 0,10 . Maka dapat disimpulkan bahwa model regresi telah memenuhi syarat multikolinieritas. 


\section{Tabel 4}

Hasil Uji Multikoloniaritas

\begin{tabular}{|c|c|c|c|c|}
\hline \multirow{2}{*}{\multicolumn{2}{|c|}{ Model }} & \multicolumn{2}{|c|}{ Collinearity Statistics } & \multirow[b]{2}{*}{ keterangan } \\
\hline & & Tolerance & VIF & \\
\hline \multirow[t]{10}{*}{1} & (Constant) & & & \\
\hline & Size Daerah & 0,599 & 1,671 & Tidak terjadi multikoloniaritas \\
\hline & Wealth & 0,330 & 3,027 & Tidak terjadi multikoloniaritas \\
\hline & Intergovermental Revenue & 0,395 & 2,532 & Tidak terjadi multikoloniaritas \\
\hline & Leverage & 0,731 & 1,368 & Tidak terjadi multikoloniaritas \\
\hline & Belanja Modal & 0,815 & 1,227 & Tidak terjadi multikoloniaritas \\
\hline & Jumlah Penduduk & 0,125 & 8,000 & Tidak terjadi multikoloniaritas \\
\hline & Ukuran Legislatif & 0,152 & 6,579 & Tidak terjadi multikoloniaritas \\
\hline & Masa Jabatan Kepala Daerah & 0,520 & 1,923 & Tidak terjadi multikoloniaritas \\
\hline & Umur Kepala Daerah & 0,587 & 1,703 & Tidak terjadi multikoloniaritas \\
\hline
\end{tabular}

\section{Uji heterokedastisitas}

Uji heterokedastisitas bertujuan untuk menguji apakah pada model regresi apakah terjadi ketidaksamaan variance dari residual satu pengamatan ke pengamatan yang lain.

\section{Tabel 5}

Hasil Uji Heterokedastisitas Model Summary ${ }^{\mathrm{b}}$

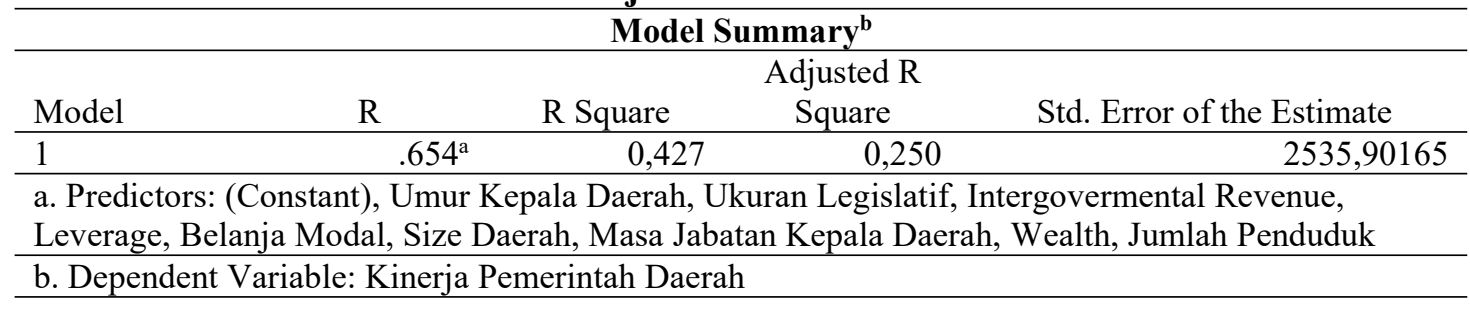

\section{Tabel 6}

Pengujian Analisis Regresi Linear berganda

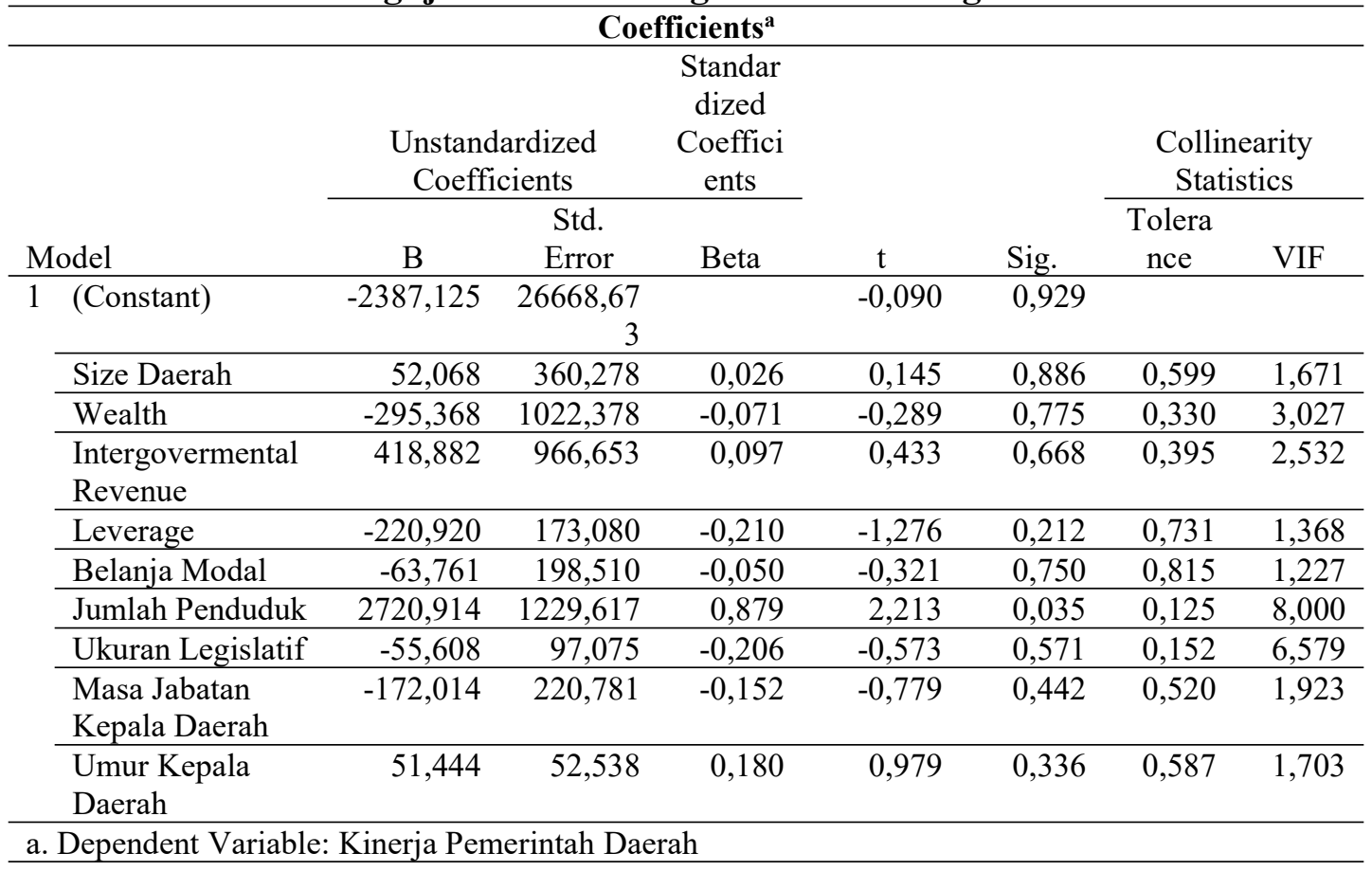


Pada tabel Chi Square, diperoleh nilai Chi Squaretabel sebesar 53.38354. Hal ini menunjukan bahwa Chi Squarehitung $<C h i$ Squaretabel. Maka dapat disimpulkan tidak terjadi heteroskedastisitas pada metode regresi, sehingga model regresi ini layak untuk digunakan dalam penelitian ini. Dari pengolahan data statistik maka diperoleh persamaan regresi linear berganda sebagai berikut:

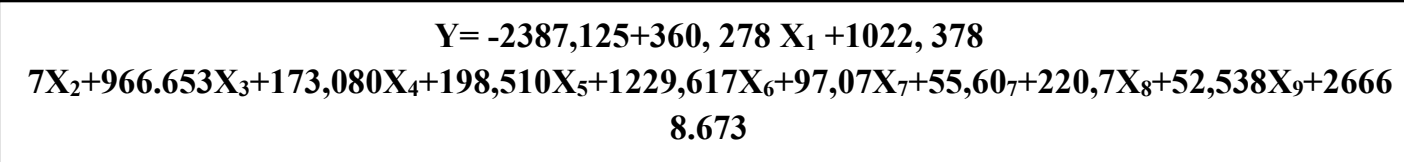

\section{Uji Kelayakan Model}

Uji F

Uji $\mathrm{F}$ bertujuan untuk mengetahui apakah variabel bebas (independen) secara bersama-sama berpengaruh terhadap variabel terikat (dependen), Ghozali (2016;96). jika $\alpha>0,05$ ditolak dan $\alpha<0,05$ diterima. Berdasarkan tabel 7, diketahui $\mathrm{F}_{\text {hitung }}$ sebesar $2.406>\mathrm{F}_{\text {tabel }}$ sebesar 2.22 dengan signifikansi $0,035^{\mathrm{b}}>0,05$. Hasil ini menunjukkan bahwa faktor keuangan yang diproksikan dengan Ukuran (Size) Pemerintah Daerah (X1), Kemakmuran (Wealth) Daerah(X2), Intergovermental Revenue (X3), Leverage (X4)dan Belanja Modal(X5) dan faktor Non keuangan di proksikan dengan Jumlah Penduduk(X6), Ukuran Legislatif(X7), Masa Jabatan Kepala Daerah(X8) dan Umur Kepala Daerah(X9) secara bersama-sama berpengaruh terhadap Kinerja Pemerintah Daerah (Y).

Tabel 7

Uji Simultan

\begin{tabular}{|c|c|c|c|c|c|c|}
\hline \multicolumn{7}{|c|}{ ANOVA $^{a}$} \\
\hline \multicolumn{2}{|c|}{ Model } & Sum of Squares & $\mathrm{df}$ & Mean Square & $\mathrm{F}$ & Sig. \\
\hline \multirow[t]{3}{*}{1} & Regression & 139249432,535 & 9 & 15472159,171 & 2,406 & $.035^{\mathrm{b}}$ \\
\hline & Residual & 186493118,439 & 29 & 6430797,188 & & \\
\hline & Total & 325742550,974 & 38 & & & \\
\hline \multicolumn{7}{|c|}{ a. Dependent Variable: Kinerja Pemerintah Daerah } \\
\hline \multicolumn{7}{|c|}{$\begin{array}{l}\text { b. Predictors: (Constant), Umur Kepala Daerah, Ukuran Legislatif, Intergovermental Revenue, } \\
\text { Leverage, Belanja Modal, Size Daerah, Masa Jabatan Kepala Daerah, Wealth, Jumlah Penduduk }\end{array}$} \\
\hline
\end{tabular}

\section{Koefisien determinasi $\mathbf{R}^{2}$}

Koefisien determinasi $\mathrm{R}^{2}$ adalah untuk mengukur tingkat kemampuan model dalam menerangkan variabel-variabel dependen, Ghozali (2016;95).

\section{Tabel 8}

\section{Pengujian Determinasi}

\begin{tabular}{|c|c|c|c|c|}
\hline \multicolumn{5}{|c|}{ Model Summary } \\
\hline Model & $\mathrm{R}$ & R Square & Adjusted R Square & Std. Error of the Estimate \\
\hline 1 & $.654^{\mathrm{a}}$ & 0,427 & 0,250 & 2535,90165 \\
\hline \multicolumn{5}{|c|}{$\begin{array}{l}\text { a. Predictors: (Constant), Umur Kepala Daerah, Ukuran Legislatif, Intergovermental Revenue, } \\
\text { Leverage, Belanja Modal, Size Daerah, Masa Jabatan Kepala Daerah, Wealth, Jumlah Penduduk }\end{array}$} \\
\hline \multicolumn{5}{|c|}{ b. Dependent Variable: Kinerja Pemerintah Daerah } \\
\hline
\end{tabular}


Dari hasil tabel di atas menunjukkan besarnya nilai Adjusted $\mathrm{R}^{2}$ adalah 0.250 atau $25 \% \mathrm{Hal}$ ini berarti bahwa variasi dari variabel dependent dapat dijelaskan oleh variasi variabel independen sebesar $25 \%$.

\section{Uji Parsial (Uji T)}

Uji t digunakan untuk melihat pengaruh masing-masing variabel bebas (independen) secara parsial terhadap variabel terikat (dependen). Kriteria penerimaan dan penolakan hipotesis adalah jika $\mathrm{T}_{\text {hitung }}>\mathrm{T}_{\text {tabel, }}$, maka Ha diterima (ada pengaruh signifikan).Jika $\mathrm{T}_{\text {hitung }}<\mathrm{T}_{\text {tabel, }}$, maka Ha ditolak (tidak ada pengaruh).

\section{Tabel 9}

Uji Parsial

\begin{tabular}{|c|c|c|c|c|c|c|}
\hline \multicolumn{7}{|c|}{ Coefficients $^{a}$} \\
\hline \multicolumn{2}{|c|}{ Model } & \multicolumn{2}{|l|}{$\begin{array}{c}\text { Unstandardiz } \\
\text { ed } \\
\text { Coefficients }\end{array}$} & \multirow{2}{*}{$\begin{array}{c}\begin{array}{c}\text { Standardiz } \\
\text { ed } \\
\text { Coefficien } \\
\text { ts }\end{array} \\
\text { Beta }\end{array}$} & \multirow[t]{2}{*}{$\mathrm{t}$} & \multirow{2}{*}{$\begin{array}{c}\text { keteran } \\
\text { gan }\end{array}$} \\
\hline & & B & Std. Error & & & \\
\hline \multirow[t]{10}{*}{1} & (Constant) & $-2387,125$ & 26668,673 & & $-0,090$ & ditolak \\
\hline & Size Daerah & 52,068 & 360,278 & 0,026 & 0,145 & ditolak \\
\hline & Wealth & $-295,368$ & 1022,378 & $-0,071$ & $-0,289$ & ditolak \\
\hline & $\begin{array}{l}\text { Intergovermental } \\
\text { Revenue }\end{array}$ & 418,882 & 966,653 & 0,097 & 0,433 & ditolak \\
\hline & Leverage & $-220,920$ & 173,080 & $-0,210$ & $-1,276$ & ditolak \\
\hline & Belanja Modal & $-63,761$ & 198,510 & $-0,050$ & $-0,321$ & ditolak \\
\hline & Jumlah Penduduk & 2720,914 & 1229,617 & 0,879 & 2,213 & diterima \\
\hline & Ukuran Legislatif & $-55,608$ & 97,075 & $-0,206$ & $-0,573$ & ditolak \\
\hline & $\begin{array}{l}\text { Masa Jabatan Kepala } \\
\text { Daerah }\end{array}$ & $-172,014$ & 220,781 & $-0,152$ & $-0,779$ & ditolak \\
\hline & Umur Kepala Daerah & 51,444 & 52,538 & 0,180 & 0,979 & ditolak \\
\hline
\end{tabular}

a. Berdasarkan tabel diketahui $\mathrm{T}_{\text {hitung }}$ sebesar $0.145<\mathrm{T}_{\text {tabel }}$ sebesar 2.045 dan nilai signifikan 0.886 $>0,05$ yang menunjukkan bahwa ukuran (size) Pemerintah Daerah tidak berpengaruh terhadap kinerja pemerintah Daerah. maka dapat disimpulkan bahwa maka $\mathrm{H}_{\mathrm{a}}$ di tolak dan $\mathrm{H}_{0}$ di terima.

b. Berdasarkan tabel diketahui $\mathrm{T}_{\text {hitung }}$ sebesar-0.289< Ttabel sebesar 2.045 dan nilai signifikan $0.775>0,05$ yang menunjukkan bahwa Kemakmuran (wealth) Pemerintah Daerah berpengaruh negatif terhadap kinerja pemerintah Daerah. sehingga dapat disimpulkan bahwa Hipotesis 2 ditolak.

c. Berdasarkan tabel diketahui $\mathrm{T}_{\text {hitung }}$ sebesar $0,433<$ Ttabel sebesar 2.045 maka $\mathrm{H}_{\mathrm{a}}$ ditolak dan nilai signifikan $0.068>0,05$ yang menunjukkan bahwa intergovermental revenue tidak berpengaruh terhadap kinerja pemerintah daerah. Sehingga dapat disimpulkan bahwa Hipotesis 3 ditolak.

d. Berdasarkan tabel diketahui $\mathrm{T}_{\text {hitung }}$ sebesar $-1726<\mathrm{T}_{\text {tabel }}$ sebesar 2.045 dan nilai signifikan 0,212>0,05 yang menunjukkan bahwa leverage berpengaruh negatif terhadap kinerja pemerintah Daerah. sehingga dapat disimpulkan bahwa Hipotesis 4 diterima.

e. Berdasarkan tabel diketahui $\mathrm{T}_{\text {hitung }}$ sebesar $-0321<\mathrm{T}_{\text {tabel }}$ sebesar 2.045 dan nilai signifikan $0.750>0,05$ yang menunjukkan bahwa Belanja Modal tidak berpengaruh terhadap kinerja pemerintah Daerah. sehingga dapat disimpulkan bahwa Hipotesis 5 ditolak. 
f. Berdasarkan tabel diketahui $\mathrm{T}_{\text {hitung }}$ sebesar $2.213>\mathrm{T}_{\text {tabel }}$ sebesar 2.045 dan nilai signifikan $0.035<0,05$ yang menunjukkan bahwa Jumlah Penduduk berpengaruh terhadap kinerja pemerintah Daerah. sehingga dapat disimpulkan bahwa Hipotesis 6 diterima.

g. Berdasarkan tabel diketahui $\mathrm{T}_{\text {hitung }}$ sebesar $-0.73<\mathrm{T}_{\text {tabel }}$ sebesar 2.045 dan nilai signifikan $0.571>0,05$ yang menunjukkan bahwa Ukuran Legislatif berpengaruh negatif terhadap kinerja pemerintah Daerah. sehingga dapat disimpulkan bahwa Hipotesis 7 ditolak.

h. Berdasarkan tabel diketahui $\mathrm{T}_{\text {hitung }}$ sebesar $-0.779<\mathrm{T}_{\text {tabel }}$ sebesar 2.045 dan nilai signifikan $0.442>0,05$ yang menunjukkan bahwa masa jabatan kepala daerah berpengaruh negative terhadap kinerja pemerintah Daerah. sehingga dapat disimpulkan bahwa Hipotesis 8 ditolak.

i. Berdasarkan tabel diketahui $\mathrm{T}_{\text {hitung }}$ sebesar $0.979<\mathrm{T}_{\text {tabel }}$ sebesar 2.045 dan nilai signifikan $0.33>0,05$ yang menunjukkan bahwa Umur Kepala Daerah tidak berpengaruh terhadap kinerja pemerintah Daerah. sehingga dapat disimpulkan bahwa Hipotesis 9 ditolak.

\section{PEMBAHASAN HASIL PENELITIAN}

Pengaruh Ukuran (Size) Pemerintah terhadap Kinerja Pemerintah Daerah di Indonesia

Hasil analisis statistik dalam penelitian ini dapat ditemukan bahwa hipotesis pertama ditolak. Ditunjukan dengan $\mathrm{T}_{\text {hitung }}$ sebesar $0.145<\mathrm{T}_{\text {tabel }}$ sebesar 2.045 dan nilai signifikan 0.886 $>0,05$ sehinggga dapat disimpulkan Ukuran (size) Pemerintah Daerah tidak berpengaruh signifikant terhadap kinerja pemerintah Daerah Kabupaten/Kota di Indonesia. Hal ini berarti bahwa besarnya total aset yang dimiliki pemerintah daerah belum mampu berkonstribusi tinggi untuk meningkatkan kinerja pemerintah daerah.

Hasil penelitian ini sejalan dengan penelitian yang dilakukan oleh Novia (2019) yang menyatakan bahwa Ukuran (size) Pemerintah Daerah tidak berpengaruh terhadap kinerja keuangan pemerintah daerah. Berbeda dengan penelitian Aminah(2019), Mustikarini dan Fitriasari (2012) dan kusumawardani (2012) yang menyatakan bahwa Size berpengaruh positif terhadap kinerja penyelenggaraan pemerintah daerah.

\section{Pengaruh Kemakmuran (Wealth) Daerah terhadap Kinerja Pemerintah Daerah}

Pada penelitian ini Variabel kemakmuran (wealth) di ukur dengan Pendapatan Asli Daerah.Berdasarkan tabel pengujian hipotesis parsial terlihat bahwa $\mathrm{H}_{\mathrm{a}}$ ditolak denganBerdasarkan tabel diketahui $\mathrm{T}_{\text {hitung }}$ sebesar-0.289< Ttabel sebesar 2.045 dan nilai signifikan 0.775 $>0,05$ sehingga menunjukan bahwa kemakmuran (Wealth) Pemerintah Daerah secara parsial tidak berpengaruh terhadap kinerja pemerintah daerah. Hal ini berarti bahwa besarnya pendapatan asli daerah yang dimiliki suatu daerah tidak mampu untuk meningkatkan kinerja pemerintah daerah.

Penelitian ini sejalan dengan penelitian Novia dan Kartim (2019) yang menyatakan bahwa variabel wealth berpengaruh negative signifikan terhadap kinerja keuangan pemerintah daerah. Hasil penelitian ini berbeda dengan penelitian yang dilakukan oleh sumarjo(2010), Aminah(2019), Kusumawardani (2012) yang menyatakan bahwa kemakmuran (wealth) berpengaruh positif terhadap kinerja pemerintah daerah.

\section{Pengaruh Intergovermental Revenue terhadap Kinerja Pemerintah Daerah}

Berdasarkan tabel pengujian hipotesis parsial terlihat bahwa variabel intergovernmental revenue tidak berpengaruh terhadap kinerja pemerintah daerah. Hal ini ditunjukkan dengan $\mathrm{T}_{\text {hitung }}$ sebesar $0,433<$ Ttabel sebesar 2.045 maka $\mathrm{H}_{\mathrm{a}}$ ditolak dan nilai signifikan $0.068>0,05$ dengan kata lain, $\mathrm{H}_{3}$ pada penelitian ini di tolak. Sehingga dapat dikatakan bahwa besarnya jumlah dana perimbangan yang dimiliki pemerintah daerah tidak berkonstribusi untuk peningkatan kinerja pemerintah daerah. 
Penelitian ini sejalan dengan penelitian Novia dan Kartim (2019), Masdiantini dan Erawati (2016), Ardian dkk (2019), Retnowati (2016) yang menyatakan bahwa intergovernmental revenue tidak berpengaruh terhadap kinerja keuangan pemerintah daerah. Hal ini dikarenakan pemerintah daerah kabupaten/kota belum dapat menggunakan dana dari pemerintah pusat dengan baik. namun berbeda dengan penelitian Aminah (2019), Indah (2016) menyatakan bahwa intergovermental revenue berpengaruh terhadap kinerja keuangan pemerintah daerah.

\section{Pengaruh leverage terhadap Kinerja Pemerintah Daerah}

Berdasarkan tabel pengujian uji parsial (Uji T) terlihat bahwa variabel leverage berpengaruh negatif terhadap kinerja Pemerintah Daerah. Hal ini ditunjukkan dengan Signifikansi (Sig) variabel leverage sebesar $\mathrm{T}_{\text {hitung }}$ sebesar $-1726<\mathrm{T}_{\text {tabel }}$ sebesar 2.045 dan nilai signifikan $0,212>0,05$. Dimana hasil penelitian menunjukan bahwa Leverage tidak berpengaruh signifikant terhadap kinerja pemerintah Daerah. Penelitian ini sejalan dngan penelitian yang dilakukan, Mirna Sesotyaningtyas(2012), Kusumawardani (2012), kartim dan Rina Novia (2015), desnia(2020) yang menyatakan bahwa leverage berpengaruh negative terhadap kinerja keuangan pemerintah daerah. Maka, dapat dikatakan bahwa pemerintah daerah belum memperhatikan tingkat utang untuk memperbaiki kinerja pemerintah daerah.

\section{Pengaruh Belanja Modal terhadap Kinerja Pemerintah Daerah di Indonesia}

Berdasarkan tabel pengujian hipotesis parsial (Uji T) terlihat bahwa variabel Belanja Modal tidak berpengaruh terhadap kinerja pemerintah daerah. Hal ini ditunjukkan dengan Signifikansi (Sig) variabel belanja modalsebesar $0321<\mathrm{T}_{\text {tabel }}$ sebesar 2.045 dan nilai signifikan $0.750>0,05$ sehingga $\mathrm{H}_{5}$ pada penelitian ini ditolak. Berdasarkan penelitian yang telah dilakukan oleh Mulyani.S dan Hardiyanto (2017) menunjukan hasil bahwa belanja modal tidak berpengaruh terhadap kinerja pemerintah. Suatu daerah memiliki belanja modal yang besar maka dapat dikatakan program-program yang akan dijalankan pemerintah daerah semakin banyak sehingga mampu meningkatkan pelayanan publik dan berdampak dapat meningkatkan kinerja pemerintah. Namun, pada penelitian ini besarnya anggaran belanja modal yang dimiliki suatu daerah tidak memberikan konstribusi untuk meningkatkan kinerja pemerintah daerah.

\section{Pengaruh Jumlah Penduduk terhadap Kinerja Pemerintah Daerah}

Berdasarkan tabel pengujian uji parsial (Uji T) menyatakan bahwa $\mathrm{T}_{\text {hitung }}$ sebesar $2.213>\mathrm{T}_{\text {tabel }}$ sebesar 2.045 dan nilai signifikan $0.035<0,05$ yang menunjukkan bahwa Jumlah Penduduk berpengaruh terhadap kinerja Pemerintah Daerah. Priyono (2018) menyatakan bahwa jumlah penduduk yang merupakan bagian dari kompleksitas pemerintahan berpengaruh kepada kinerja fiskal daerah. Hal ini berarti semakin besar jumlah penduduk maka akan semakin tinggi kinerja keuangan daerah. Bertambahnya jumlah penduduk mengakibatkan objek pajak dan retribusi bertambah luas sehingga penerimaan daerah pun juga meningkat, dan kinerja pemerintah dalam memberikan pelayanan publik juga akan semakin baik.

\section{Pengaruh Ukuran Legislatif terhadap Kinerja Pemerintah di Indonesia.}

Berdasarkan pengujian uji parsial (Uji T) diketahui $\mathrm{T}_{\text {hitungsebesar }} 0.195<\mathrm{T}_{\text {tabel }}$ sebesar 1.697 dan nilai signifikan $0,847>0,05$ yang menunjukkan bahwa Ukuran Legislatif tidak berpengaruh terhadap kinerja pemerintah Daerah. Maka dapat dikatakan bahwa tingkat pengawasan anggota DPRD belum optimal. Besarnya jumlah anggota DPRD diharapkan dapat meningkatkan pengawasan terhadap pemerintah daerah sehingga berdampak dengan adanya peningkatan kinerja pemerintah daerah Sumarjo (2010). 


\section{Pengaruh Masa Jabatan Kepala Daerah terhadap Kinerja Pemerintah di Indonesia}

Berdasarkan tabel pengujian uji parsial (Uji T) diketahui $-0.779<\mathrm{T}_{\text {tabel }}$ sebesar 2.045 dan nilai signifikan 0.442>0,05yang menunjukkan bahwa masa jabatan kepala tidak berpengaruh terhadap kinerja pemerintah Daerah. sehingga dapat dikatakan bahwa lamanya seseorang menjabat tidak menjamin kualitas kerjanya.

Pengalaman kepala daerah dapat dikaitkan dengan lamanya masa jabatan Semakin lama masa jabatannya maka semakin banyak pula pengalaman yang dimiliki. Pengalaman kerja yang cukup yang dimiliki oleh kepala daerah diharapkan bisa beradaptasi dengan perubahan yang terjadi dan diharapkan dapat membuat suatu hal yang baru untuk mencapai kinerja pemerintah yang baik, Sutaryo (2013). Kepala Daerah merupakan orang terpercaya untuk menjalankan suatu pemerintahan.

\section{Pengaruh Umur Kepala Daerah terhadap kinerja Pemerintah di Indonesia}

Berdasarkan tabel diketahui $\mathrm{T}_{\text {hitung }}$ sebesar $0.979<\mathrm{T}_{\text {tabel }}$ sebesar 2.045 dan nilai signifikan $0.33>0,05$ yang menunjukkan bahwa Umur Kepala Daerah tidak berpengaruh terhadap kinerja pemerintah Daerah. Maka dapat dikatakan bahwa besar atau kecil umur seorang kepala daerah tidak menentukan kualitas kerjanya. Penelitian mengenai umur kepala daerah juga telah dilakukan oleh Misdi (2015) yang memperoleh hasil bahwa umur kepala daerah berpengaruh secara signifikan terhadap kinerja keuangan daerah.

\section{KESIMPULAN DAN SARAN KESIMPULAN}

Berdasarkan hasil pengujian dan pembahasan yang telah dijelaskan pada Bab IV maka dapat ditarik kesimpulan bahwa faktor keuangan pada penelitan ini tidak berpengaruh terhadap kinerja pemerintah daerah. Selain itu, faktor Non keuangan hanya Jumlah penduduk yang berpengaruh terhadap kinerja pemerintah daerah.

Ada beberapa keterbatasan pada penelitian ini. Pertama, Penelitian ini hanya penggunakan sampel sebanyak 39 Kabupaten/Kota di Indonesia tahun 2018 karena banyak kabuapten/kota yang belum publikasi LKPD tahun 2018 sehingga hasil penelitian belum mampu mewakili seluruh Pemerintah Daerah kabupaten/kota di Indonesia. Kedua, pada penelitian ini, banyak variabel independen yang tidak berpengaruh pada variabel dependen sehingga dalam penelitian ini belum dapat menjelaskan hal-hal yang $\mathrm{t}$ mempengaruhi kinerja pemerintah daerah. Hal ini dapat dilihat dari Adjusted $\mathrm{R}^{2}$ adalah 0.250 atau $25 \%$ yang dipengaruhi oleh variabel independen sedangkan sisanya sebesar $75 \%$ dijelakan oleh variabel lain yang tidak diteliti pada penelitian ini.

Terdapat beberapa kontribusi dan saran yang dapat diambil dari penelitian ini. Pertama, bagi pemerintah daerah di Indonesia, diharapkan dapat meningkatkan pendatan asli daerah dengan menggali potensi-potensi yang ada di daerah masing-masing agar pemerintah daerah tidak bergantung lagi pada pemerintah pusat, sehingga tercapai kemakmuran suatu daerah dan pemerintah kabupaten kota di Indonesia mampu memperoleh skor dan memperoleh peringkat sangat tinggi. Kedua, bagi peneliti selanjutnya diharapkan dapat melakukan penelitian dengan lingup yang lebih besar agar penelitian ini lebih jelas dan lebih lengkap agar hasil penelitian dapat mewakili seluruh pemerintah kabupaten/kota di Indonesia. Dan peneliti selanjutnya selanjutnya diharapkan dapat menambah serta menggunakan variabel bebas lain yang relevan dengan kinerja pemerintah daerah. 


\section{DAFTAR PUSTAKA}

Aminah, Iim Nur, Nunuy Nur Afiah, And Arie Pratama. (2019). Pengaruh Size, Wealth, Intergovermental Revenue Dan Belanja Modal Terhadap Kinerja Pemerintah Daerah. Jurnal SIKAP (Sistem Informasi, Keuangan, Auditing Dan Perpajakan) 3 (2): 147. Https://Doi.Org/10.32897/Jsikap.V3i2.137.

Bastian, I. (2006). Akuntansi Sektor Publikdi Indonesia.Yogyakarta: BPFE.

Darmanto, HC. (2012).Perpustakaan.Uns.Ac.Id Digilib. 3 (September): 1-47.

Gilligan, Thomas W., And John G. Matsusaka. (2001). Fiscal Policy, Legislature Size, And Political Parties: Evidence from State and Local Governments in The First Half of the 20th Century. National Tax Journal 54 (1): 57-81. Https://Doi.Org/10.17310/Ntj.2001.1.03.

Ghozali, I. (2011). Aplikasi Analisis Multivariante Dengan Program SPSS. Edisi V. Semarang: Badan Penerbit UNDIP.

Halim, A. (2012). Akuntansi Keuangan Daerah.Yogyakarta: Salemba Empat. Hurlock, Elizabeth B. (2004). Developmenral Psychology. Jakarta: Erlangga.

Jensen, M. C., \& Meckling, W. H. (1976). Theory Of The Firm. Managerial

Behavior, Agency Costs And Ownership Structure. Journal of Financial Economics, 3(4): 305-360.

Kartim Dan Novia Rina. (2015). Acc - JU / 2019 Daerah Keuangan Pemerintah Dimiliki Dapat Mendukung Kinerja Pemerintah Daerah. Aset Yang Besar.

Kusumawardani. (2012). Pengaruh Size, Kemakmuran, Ukuran Legislatif, Leverage Terhadap Kinerja Keuangan Pemerintah Daerah Di Indonesia." AAJ.

Kemendagri No. 100-53 Tahun 2018 Tentang Keputusan Peringkat Dan Status Kinerja Penyelenggaraan Pemerintah Daerah.

Lastiar Hutapea, Hutapea, And Aristanti Widyaningsih. (2017). Pengaruh Good Government Governance Dan Ukuran Legislatif Terhadap Kinerja Pemerintah Daerah (Studi Pada Pemerintah Provinsi di Indonesia). Jurnal ASET (Akuntansi Riset) 9 (1): 173. Https://Doi.Org/10.17509/Jaset.V9i1.5446.

Mahmudi. (2016). Analisis Laporan Keuangan Pemerintah Daerah. Yogyakarta: UPP STIM YKPN.

Mardiasmo. (2009). Akuntansi Sektor Publik. Yogyakarta: Penerbit ANDI.

Masdiantini, Putu, And Ni Erawati. (2016). Pengaruh Ukuran Pemerintah Daerah, Kemakmuran, Intergovernmental Revenue, Temuan Dan Opini Audit Bpk Pada Kinerja Keuangan.E-Jurnal Akuntansi.

Mirna, Sesotyaningtyas. (2012). Pengaruh Leverage, Ukuran Legislatif, Intergovernmental Revenue Dan Pendapatan Pajak Daerah Terhadap Kinerja Keuangan Pemerintah Daerah." Accounting Analysis Journal 1 (1). Https://Doi.Org/10.15294/Aaj.V1i1.711.

Misdi. (2015). Pengaruh Karakteristik Kepala Daerah Terhadap Kinerja Keuangan Daerah. Keuangan Daerah (Studi Empiris Pada Pemerintah Daerah Kabupaten / Kota Di Jawa Timur Tahun 2011 S . D . 2012): Surakarta: Digilib.Uns.Ac.Id.

Mulyani.S Dan Hardiyanto, W. (2017). Journal Of Chemical Information And Modeling 53 (9): 1689-99. Https://Doi.Org/10.1017/CBO9781107415324.004.

Mustikarini, Widya Astuti, And Debby Fitriasari. (2007). Pengaruh Karakteristik Pemerintah Daerah Dan Temuan Audit BPK Terhadap Kinerja Pemerintah Daerah Kabupaten/Kota Di Indonesia Tahun Anggaran 2007. Simposium Nasional Akuntansi (SNA) XV Banjarmasin.

Nugroho, Fajar, And Abdul Rohman. (2012). Pengaruh Belanja Modal Terhadap Pertumbuhan Kinerja Keuangan Daerah Dengan Pendapatan Asli Daerah Sebagai Variabel Intervening. Diponogoro Journal of Accounting 1 (2): 1-14. Https://Ejournal3.Undip.Ac.Id/Index.Php/Accounting/ Article/Download/38/51. 
Patriati.Ratri. (2010). Analisis Faktor-Faktor Yang Mempengaruhi Kinerja Keuangan Emerintah Daerah Di Jawa Tengah.

Permendagri No 73 Tahun 2009. Peraturan Menteri Dalam Negeri No 73 Tentang Tata Cara Pelaksanaan Evaluasi Kinerja Penyelenggaraan Pemerintahan Daerah.

Prayitno, S. (2012). Pengaruh Karakteristik Keuangan Pemerintah Daerah Dan Karakteristik Kepala Daerah Terhadap Kinerja Keuangan Pemerintah Daerah. Tesis. Universitas Sebelas Maret.

Rochmah, S, N. (2015). Journal Of Banking And Finance 5 (1): 643-54. Https://Doi.Org/10.1016/J.Jbankfin.2017.09.006.

Sari, I. P. (2016). Pengaruh Ukuran Pemerintah Daerah, PAD, Leverage, Dana Perimbangan Dan Ukuran Legislatif Terhadap Kinerja Keuangan Pemerintah Daerah. JOM Fekom, Vol. 3, No. 1, 679-692

Sudarsana, Hafidh Susila, And Shiddiq Nur Rahardjo. (2013). Dan Temuan Audit Bpk Terhadap Kinerja. Diponegoro Journal of Accounting 2 (6): 1-13.

Sumarjo, Hendro. (2010). Pengaruh Karakteristik Pemerintah Daerah Terhadap Kinerja Keuangan Pemerintah Daerah ( Studi Empiris Pada Pemerintah Daerah Kabupaten / Kota Di Indonesia ). Skripsi.

Sutaryo. (2013). Karakteristik Eksekutif Dan Kinerja Keuangan Pemerintah Daerah. Urusan Akuntansi FE UNS Sutaryofe.Staff.Uns.Ac.Id.Sugiyono. (2012). Metode Penelitian Kuantitatif Kualitatif Dan R\&D. Bandung: Alfabeta.

Tama, I Gusti Made Ary Anggara, And Priyo Hari Adi. (2018). Pengaruh Karakteristik Kepala Daerah, Ukuran Pemerintah, Dan Temuan Audit Terhadap Kinerja Keuangan Daerah.

Undang Undang No 33 Tahun 2004 Tentang Perimbangan Keuangan.

Undang-Undang Dasar Tahun 1945 Pasal 2 Ayat 2 Tentang Majelis Permusyawaratan Rakyat.

Undang-Undang Republik Indonesia Nomor 33 Tahun 2004 Tentang Perimbangan Keuangan.15 Oktober 2004. Lembaran Negara Republik Indonesia Tahun 2004 Nomor 126. Jakarta.

Undang-Undang Republik Indonesia Nomor 23 Tahun 2014 Tentang Pemerintah Daerah.2 Oktober 2014. Lembaran Negara Republik Indonesia Tahun 2014 Nomor 244. Jakarta.

Undang-Undang No. 28 Tahun 2009, Tentang Pajak Daerah Dan Retribusi Daerah. 